\title{
Bacterial Expression of the scFv Fragment of a Recombinant Antibody Specific for Burkholderia pseudomallei Exotoxin
}

\author{
Yu-Ching Su, Kue-Peng Lim and Sheila Nathan* \\ Centre for Gene Analysis and Technology, Faculty of Science and Technology, Universiti Kebangsaan Malaysia, \\ 43600 UKM Bangi, Selangor D.E., Malaysia
}

Received 18 March 2003, Accepted 24 April 2003

\begin{abstract}
The scFv antibody towards the Burkholderia pseudomallei exotoxin was previously constructed by phage display and exhibited good specificity towards the exotoxin. We report here the optimization of the scFv expression in an E. coli expression system. Four different E. coli strains (ER2537, TG1, HB2151, and XL1-Blue) were examined for optimal expression of the scFv protein. Two types of carbon source (i.e. $0.2 \%$ glucose and $0.2 \%$ glycerol) were also tested for their ability to induce the scFv expression. Cells that carried the $\mathrm{scFv}$ construct were grown at $30^{\circ} \mathrm{C}$ and induced with $0.05 \mathrm{mM}$ IPTG. The expression was then monitored by SDS-PAGE, Western blotting, and indirect ELISA. The Western blot profile showed different levels of the scFv expression among the host strains; XL1-Blue exhibited the highest level of the $\mathbf{s c F v}$ protein expression. Glycerol at a concentration of $0.2 \%(\mathrm{v} / \mathrm{v})$ significantly increased the $\mathrm{scFv}$ protein expression level when compared to $0.2 \%(\mathrm{w} / \mathrm{v})$ glucose. Further optimization demonstrated that the scFv protein expression in XL1-Blue was the most optimal with a glycerol concentration as low as $\mathbf{0 . 0 5 \%}$. However, by indirect ELISA, only the scFv protein that was expressed in $0.2 \%(\mathrm{v} / \mathrm{v})$ glycerol exhibited high specificity towards the Burkholderia pseudomallei exotoxin.
\end{abstract}

Keywords: Antibody, E. coli, Exotoxin, Protein expression, $\mathrm{ScFv}$

\section{Introduction}

Melioidosis, an important health problem for humans and livestock, is a potentially fatal disease that is caused by a soil bacterium, Burkholderia pseudomallei (formerly Pseudomonas

*To whom correspondence should be addressed.

Tel: 603-8921-3862; Fax: 603-8925-2698

E-mail: sheila@pkrisc.cc.ukm.my pseudomallei). Although the disease is endemic in Southeast Asia and Nothern Australia with incidences that correlate with rainfall, melioidosis cases have been encountered in temperate areas, such as France (Thibault et al., 1996). Melioidosis is associated with underlying predisposing conditions (such as diabetes and renal failure) and can range in presentation from a fulminant septicemic illness to an indolent local infection (Chaowagul et al., 1993). B. pseudomallei virulence factors have been investigated since 1950, but they are still poorly characterized. The bacterium is known to secrete various extracellular products which have been implicated in the pathogenesis of this disease. These products include exotoxin (a heat labile lethal toxin) (Ismail et al., 1987b), hemolysin (Ashdown and Koehler, 1990), phosphatase acid (Kanai and Kondo, 1994) and protease (Ismail et al., 1987a; Vorachit et al., 1995; Ling et al., 2001). Recently, the purification and characterization of cytotoxic exolipid has been described (Hausesler et al., 1998). It is believed that the exotoxin is responsible for the rapid onset of the disease and dramatic course of septicaemic melioidosis. This lethal pathogenic factor manifests its cytotoxic effects by the inhibition of cellular protein synthesis via ADP-ribosylation of the elongation factor-2 (EF-2), and hence attenuates the host immune system during B. pseudomallei infection (Rahmah et al., 1989).

Diagnosis of melioidosis is currently limited to techniques that are based on clinical features (Yabuuchi and Arakawa, 1993), serological examination, and bacteriological methods (Puthucheary, 1994). These are time consuming and generally too late to be useful. The ability to detect exotoxin in the serum at a concentration of $16 \mathrm{ng} / \mathrm{ml}$ by an anti-exotoxin monoclonal antibody through the enzyme-linked immunosorbent assay (ELISA) technique led to the utilization of the monoclonal antibody in a laboratory diagnosis of animal and human melioidosis (Ismail et al., 1987a; Ismail et al., 1991).

We previously described the production and characterization of monoclonal antibodies against the exotoxin (Nathan et al., 2000). These antibodies are useful for 
analysis of the structure-function relationship of the exotoxin to understand its role in the pathogenesis of melioidosis. This could be approached by the use of epitope mapping of the antigen by the monoclonal antibodies and the subsequent purification of the epitope. Nevertheless, the hybridoma cell line that secrets the monoclonal antibodies, 6E6A8F3B, was not very stable in culture, and the secreted antibodies also demonstrated non-specific binding to other B. pseudomallei extracellular pathogenic products. As a result of the low stability and low specificity of the hybridoma line, we cloned the single chain variable fragment $(\mathrm{scFv})$ of the monoclonal antibody by phage display (Nathan et al., 2002). An scFv antibody with a molecular size of $25 \mathrm{kDa}$ is the smallest antibody structure that retains the binding properties of the parent antibody, and it has a better penetration of solid tissue and rapid clearance of unbound antibody from the circulation (George, 1995). To construct the scFv antibody, the heavy and light chain variable domains of the monoclonal antibody 6E6A8F3B (Nathan et al., 2000) were cloned, and use of the phage display enabled the specific selection and improvement of binding affinities of the anti-exotoxin antibody toward the exotoxin. The $\mathrm{scFv}$ gene was subsequently subcloned from the original expression vector $\mathrm{pComb3H}$ to $\mathrm{pComb} 3 \mathrm{X}$ ( Lim et al., manuscript in preparation), because the latter vector allows better detection and purification of the expressed products (Rader and Barbas, 1997). The vast number of vectors available for the expression and manipulation of cloned genes, and complete information of the Escherichia coli genome have encouraged the use of $E$. coli as a protein expression host (Karu et al., 1995). In this study, we describe the optimization of the $\mathrm{scFv}$ expression towards $B$. pseudomallei exotoxin by utilizing various $E$. coli host cell strains and different concentrations of carbon sources. In our quest to produce a vaccine and diagnostic tool for melioidosis, the optimal $\mathrm{scFv}$ expression will permit the large scale expression of the anti-B. pseudomallei exotoxin $\mathrm{scFv}$ that is necessary for exotoxin purification by affinity chromatography.

\section{Materials and Methods}

\section{Materials \\ Vector and clone The pComb3X vector $(4.8 \mathrm{~kb})$ (Barbas et al., 2001) and Clone C4X (3.95 kb), a recombinant antibody clone consisting of the anti-B. pseudomallei exotoxin $\mathrm{scFv}$ gene (750 bp) (Nathan et al., 2002), were cloned into the expression vector pComb3X (3.2 kb) (Lim et al., manuscript in preparation). Both pComb3X and Clone C4X were carried within the E. coli strain ER2537 (New England Biolabs, Beverly, USA).}

\footnotetext{
Methods

Burkholderia pseudomallei exotoxin B. pseudomallei exotoxin was prepared as previously described (Ismail et al., 1987a; Nathan et al., 2000).
}

Bacterial host strains Both the vector and clone $\mathrm{C} 4 \mathrm{X}$ were transformed and expressed in the E. coli strain ER2537 [ $\lambda^{-} \mathrm{F}^{\prime}$ lac $I^{a} \Delta$ (lacZ)M15 pro $A^{+} B^{+} /$fhuA2 supEA(lac-proAB) thi $\Delta$ (hsdMSmerB) $5\left(\mathrm{r}_{\mathrm{k}}{ }^{-} \mathrm{m}_{\mathrm{k}}{ }^{-} \mathrm{McrBC}\right.$ ) $\mathrm{K} 12$ ], TG1 (Stratagene) [supE thi 1- $\Delta$ (lacproAB) $\Delta(m c r B-h s d S M) 5\left(\mathrm{r}_{\mathrm{k}}^{-} \mathrm{m}_{\mathrm{k}}^{-}\right)\left[\mathrm{FtraD} 36\right.$ proAB lacl $\left.{ }^{1} \mathrm{Z} \Delta M 15\right] \mathrm{K} 12$, XL1-Blue (Stratagene, La Jolla, USA) [recl endA1 gyrA96 thilhsd R17 SupE44 recl lac [F' proAB lacl ${ }^{4}$ Z $\Delta M 15$ Tn10 (Tet') K12] and HB2151 (Stratagene) [araD (lac pro $A B$ ), lac $^{q} \Delta$ (lacZ) M15, thi/F' $\operatorname{proA}^{+} B^{+} /$fhua2 $\Delta\left(\right.$ thi $\Delta$ (hsdMSmerB) $\left({ }^{-} \mathrm{r}_{\mathrm{k}}{ }^{-} \mathrm{m}_{\mathrm{k}}^{-}\right.$McrBC $)$ K12].

ER2537, TG1, and XL1-Blue are amber codon (UAG) suppressor strains, while HB2151 is an amber codon nonsuppressor strain.

Bacterial growth Stock cells of E. coli ER2537 that carry either pComb3X vector (ER-3X) or Clone C4X (ER-C4X) were respectively streaked onto Luria-Bertani (LB) agar that contained $50 \mu \mathrm{g} / \mathrm{ml}$ carbenicilin and incubated overnight at $37^{\circ} \mathrm{C}$. A single colony was used to inoculate $10 \mathrm{ml}$ Superbroth (SB) medium that contained $50 \mu \mathrm{g} / \mathrm{ml}$ carbenicilin. The inoculums were grown overnight at $37^{\circ} \mathrm{C}$ with agitation. These cultures were then used for the phagemid DNA extraction and production of the infectious phage that carried the $\mathrm{pComb} 3 \mathrm{X}$ vector and Clone C4X.

Phagemid DNA extraction The pComb3X and Clone C4X phagemid DNA were extracted with a Qiagen Miniprep Kit (Hilden, Germany), according to the manufacturers protocol. The extracted DNA were subsequently digested with Sfi I (15 U) (Promega, Madison, USA) at $50^{\circ} \mathrm{C}$ for $5 \mathrm{~h}$ to confirm the presence of the $\mathrm{scFv}$ gene in Clone $\mathrm{C} 4 \mathrm{X}$, prior to performing the protein expression. The digested products were analysed by $0.9 \%$ agarose gel electrophoresis.

Amplification of infectious phage carrying pComb3X and Clone C4X Overnight cultures of ER-C4X and ER-3X were used to produce phage. Five $\mathrm{ml}$ of each overnight culture were added to $45 \mathrm{ml}$ of the SB medium that contained $50 \mu \mathrm{g} / \mathrm{ml}$ carbenisilin. They were then incubated at $37^{\circ} \mathrm{C}$ for $1 \mathrm{~h}$ with agitation. This was followed by adding $2 \mathrm{ml}$ of the VCSM13 helper phage (titer $10^{11}$ $\mathrm{ml}^{-1}$; Stratagene) and incubating for a further $2 \mathrm{~h}$ at $37^{\circ} \mathrm{C}$. Kanamycin $(0.5 \mathrm{mg} / \mathrm{ml})$ was then added and the mixture was incubated overnight at $37^{\circ} \mathrm{C}$. On the following day, the overnight cultures were pelleted by centrifugation at $6,000 \times g$ for $15 \mathrm{~min}$ at $4^{\circ} \mathrm{C}$. The phage was precipitated with $12 \mathrm{ml}$ PEG8000/ $\mathrm{NaCl} 5 \mathrm{X}$, filtered through a Minisart filter (pore size $0.45 \mu \mathrm{m}$ ), and stored at $20^{\circ} \mathrm{C}$.

Transfection of host cell strains TG1, XL1-Blue, and HB2151 Clone C4X and pComb3X DNA were directly introduced into the log phase TG1, XL1-Blue, and HB2151 host cells by transfection of the infectious phage that carried the DNA. The transfectants were incubated at room temperature for $30 \mathrm{~min}$ and plated onto LB agar containing carbenisilin overnight at $37^{\circ} \mathrm{C}$.

Recombinant scFv expression Prior to the induction of the $\mathrm{scFv}$ expression $0.2 \%(\mathrm{v} / \mathrm{v})$ glycerol or $0.2 \%(\mathrm{w} / \mathrm{v})$ glucose was added to the ER2537, TG1, XL1- Blue, and HB2151 cells that carried C4X. The cultures were then incubated for $4-5 \mathrm{~h}$ at $30^{\circ} \mathrm{C}$ until the $\log$ phase (optical density (OD) at $600 \mathrm{~nm}$ was approximately 0.5 ). 
To initiate the expression of the recombinant antibody genes, the cells in the log phase were induced by adding $0.05 \mathrm{mM}$ isopropyl$\beta$-D-thio-galactopiranoside (IPTG) (Promega) and followed by incubation for a further $5 \mathrm{~h}$ at $30^{\circ} \mathrm{C}$. Appropriate negative controls that were utilised included host cells, host cells carrying pComb3X, and the absence of IPTG and carbon sources.

Cell harvesting and extract preparation The cultures were pelleted by centrifugation at $2,600 \times g$ for $20 \mathrm{~min}$ at $4^{\circ} \mathrm{C}$. The supernatants were stored at $-20^{\circ} \mathrm{C}$. The cell suspensions were disrupted by freeze-thawing and the periplasmic products were stored at $-20^{\circ} \mathrm{C}$.

Detection of scFv antibody fragment by Western blotting The production of the $\mathrm{scFv}$ fragment was detected by Western blotting (Towbin et al., 1979) and quantified by a qualitative comparison.Twenty $\mu \mathrm{g}$ of the expression product for each culture was initially separated on a $12 \%$ discontinuous SDSpolyacrylamide gel (Laemmli, 1970).

Following the SDS-gel electrophoresis, the separated proteins were transferred onto a nitrocellulose membrane (Osmonics, Downers Grove, USA) and blocked overnight in $5 \%$ (w/v) milk powder in PBS at $4^{\circ} \mathrm{C}$, followed by four 10 min-washes in $0.1 \%$ (v/ v) Tween 20 in PBS (PBST). The membrane was then incubated in peroxidase-conjugated mouse secondary anti-hemagglutinin (antiHA) (1:500), and $500 \mu \mathrm{l}$ of HRP Supersignal substrate was added. The reaction was detected by exposing the membrane to X-ray film.

Indirect enzyme-linked immunosorbent assay (ELISA) Ninety six-well plates (Nunc, Roskilde, Denmark) were coated overnight with $100 \mu \mathrm{l}$ B. pseudomallei exotoxin $(1 \mathrm{mg} / \mathrm{ml})$ in a coating buffer $\left(0.1 \mathrm{M} \mathrm{NaHCO}_{3}, \mathrm{pH}\right.$ 8.6). The plate was blocked for $1 \mathrm{~h}$ at $37^{\circ} \mathrm{C}$ with $5 \%(\mathrm{w} / \mathrm{v})$ milk powder and $100 \mu \mathrm{l}$ of each sample (primary antibody) was added to the wells. Peroxidase-conjugated anti-HA $(1: 500)$ was used as the secondary antibody, while the ABTS : peroxidase $(1: 1)$ solution was used as the substrate. The reaction was monitored at OD $405 \mathrm{~nm}$ on Dynex MRX ELISA Reader.

\section{Results and Discussion}

The aim of this study was to optimize the $\mathrm{scFv}$ anti- $B$. pseudomallei exotoxin expression through selection of a suitable host strain and carbon source. All of the expression products were analysed by Western blotting and indirect ELISA.

Transfection The phagemid DNA that is carried by all four host strains was extracted and digested with Sfi I to confirm the presence of the insert prior to protein expression. Digestion of Clone C4X confirmed the presence of the $750 \mathrm{bp}$ scFv gene which had previously been inserted into pComb3X (Fig. 1). Digested pComb3X produced the non-coding stuffer of $1.6 \mathrm{~kb}$ which was used as a control insert to preclude the gene III expression in the $\mathrm{pComb} 3 \mathrm{X}$ vector by destroying the reading frame of gene III (Amstrong et al., 1995). The reading frame was restored within the clone when the stuffer fragment

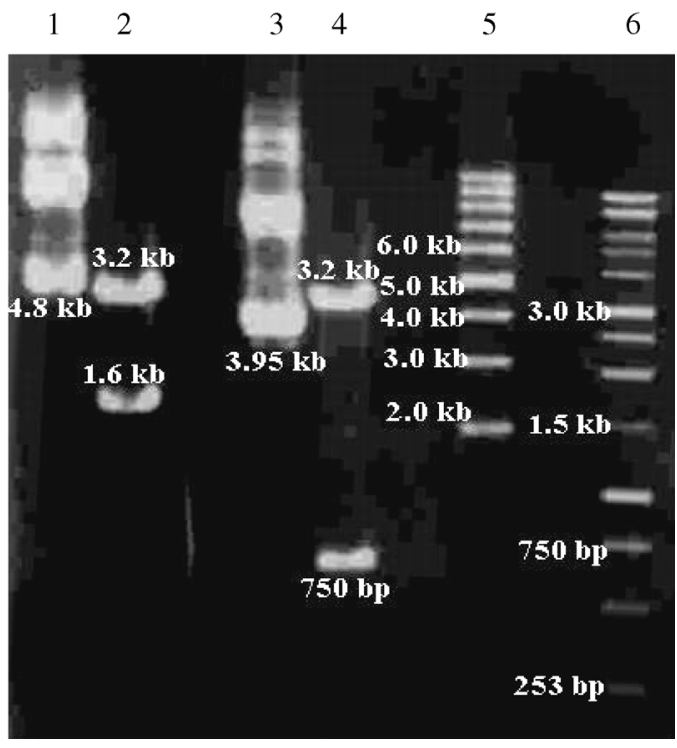

Fig. 1. Phagemid DNA extraction and Sfi I digestion profile. Lane 1: Undigested pComb3X vector $(4.8 \mathrm{~kb})$. Lane 2: Digested pComb3X (3.2 kb vector and $1.6 \mathrm{~kb}$ stuffer fragment). Lane 3: Undigested Clone C4X (3.95 kb). Lane 4: Digested Clone C4X (750 bp scFv gene and $3.2 \mathrm{~kb}$ vector). Lane 5: Supercoil DNA ladder. Lane 6: $1 \mathrm{~kb}$ DNA ladder.

was replaced with the $\mathrm{scFv}$ gene (Andris-Widhopf et al., 2000).

Recombinant scFv expression The $\mathrm{scFv}$ gene was inserted downstream of the lac promoter between the leader sequence OmpA and gene III to construct Clone C4X (Lim et al., manuscript in preparation). The expression of the genes cloned downstream of the lac promoter can be conveniently induced by the addition of IPTG (De Bellis and Schwartz, 1990). All of the host cells that were used have the lac $I^{q}$ genotype to limit the background expression from the lac promoter. This also ensures that the expression only occurs upon the induction by IPTG as constitutive expression, which would almost certainly be detrimental and debilitating to the host (Carrier et al., 1993). Overproduction of foreign proteins that are encoded within the DNA that is introduced into the host cell will trigger the metabolic burden phenomenon (Glick, 1995); therefore, the IPTG concentration that was used in this study was limited to $0.05 \mathrm{mM}$ (Donovan et al., 2000).

Many factors can affect the efficiency of the expression (e.g. choice of nutrients and environmental parameters, such as temperature, dissolved oxygen tension, etc.). The expression of foreign proteins in a recombinant host cell often utilizes significant amounts of host cell resources, which places a metabolic burden on the host. It leads to a decrease in growth and a reduction of the protein expression. Therefore, to enhance the protein expression in this study, a concentration of $0.2 \%$ glucose $(\mathrm{w} / \mathrm{v})$ or glycerol $(\mathrm{v} / \mathrm{v})$ was added to the growth medium (Donovan et al., 2000). Growth was 
a. ER2537

$\begin{array}{llllllllll}1 & 2 & 3 & 4 & 5 & 6 & 7 & 8 & 9 & 10\end{array}$ b. TG 1

$\begin{array}{llllllllll}1 & 2 & 3 & 4 & 5 & 6 & 7 & 8 & 9 & 10\end{array}$
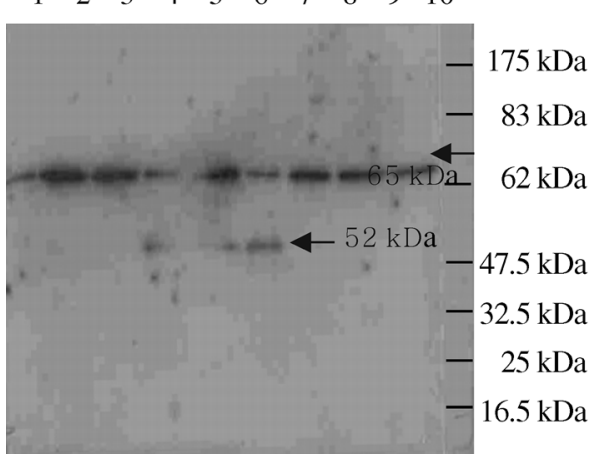

c. XL1-Blue

$\begin{array}{llllllllll}1 & 2 & 3 & 4 & 5 & 6 & 7 & 8 & 9 & 10\end{array}$

Fig. 2. Western blot profile of proteins expressed in the periplasm under induction of $0.05 \mathrm{mM}$ IPTG. Glycerol feeding significantly increased the scFv expression with the optimal expression occuring in XL1-Blue Clone C4X. Lane 1: Host cell without additional carbon source. Lane 2: Host cell with $0.2 \%$ glucose. Lane 3: Host cell with $0.2 \%$ glycerol. Lane 4: Host cell Clone C4X without additional carbon source. Lane 5: Host cell Clone C4X with 0.2\% glucose. Lane 6: Host cell Clone C4X with 0.2\% glycerol. Lane 7: Host cell pComb3X without additional carbon source. Lane 8: Host cell pComb3X with $0.2 \%$ glucose. Lane 9: Host cell pComb3X with $0.2 \%$ glycerol. Lane 10: Protein marker.

maintained at $30^{\circ} \mathrm{C}$ to enhance the production of correctlyfolded functional scFv antibodies (Glick, 1995).

The proteins that were expressed in the extracellular culture medium and periplasm were separated by SDS-PAGE to retain the $\mathrm{scFv}$ protein as a single chain polypeptide and prevent the formation of diabodies. The $\mathrm{scFv}$ that was expressed in this study was fused to a nine amino acid peptide hemaglutinin (HA) at the carboxyl terminal, which enabled the detection of the $\mathrm{scFv}$ by secondary-conjugated anti-HA via Western blotting. The $\mathrm{scFv}$ proteins were only detected in the host cells that carried $\mathrm{C} 4 \mathrm{X}$, and not in the controls (host cells as well as host cells containing pComb3X alone) (Fig. 2 and 3).

In the absence of the inducing agent (IPTG), the $\mathrm{scFv}$ proteins were detected only in the periplasm of ER2537, TG1, and XL1-Blue cells that carried C4X (data not shown). This implied that in the absence of an inducer and in the presence of the lac repressor, there was a basal level expression from the lac promoter. No $\mathrm{scFv}$ protein was detected in the extracellular medium of all of the hosts for C4X (data not shown). This included the non-suppressor HB2151 which was expected to show secretion of soluble scFv into the growth medium.

The expression of the scFv protein by the lac promoter was activated in the presence of IPTG (Fig. 2 and 3). The scFv protein $(52 \mathrm{kDa})$ were clearly detected from $\mathrm{C} 4 \mathrm{X}$ in all of the hosts periplasm with the exception of HB2151 (Fig. 2). Several bands of low molecular weight were also detected by Western blotting. These could be due to either endogenous protease digestion or an internal start codon, ATG, that was preceded by a suitably-spaced ribosome binding site (RBS). The $\mathrm{scFv}$ protein in the extracellular medium was detected only in the HB2151 Clone C4X, as a band of $30 \mathrm{kDa}$ (Fig. 3). This was a result of the secretion of soluble scFv from the periplasm into the extracellular growth medium. The $\mathrm{scFv}$ anti-B. pseudomallei exotoxin that was expressed in the amber codon (UAG) suppressor strains (ER2537, TG1, and XL1-

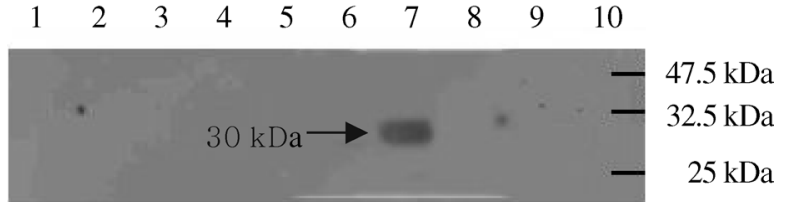

Fig. 3. Western blot profile of proteins expressed into the extracellular medium of HB2151 upon induction by $0.05 \mathrm{mM}$ IPTG. Lane 1: HB2151 without additional carbon source. Lane 2: HB2151 with $0.2 \%$ glucose. Lane 3: HB2151 with $0.2 \%$ glycerol. Lane 4: HB2151 Clone C4X without additional carbon source. Lane 5: HB2151 Clone C4X with $0.2 \%$ glucose. Lane 6: HB2151 Clone C4X with $0.2 \%$ glycerol. Lane 7: HB2151 pComb3X without additional carbon source. Lane 8: HB2151 pComb3X with $0.2 \%$ glucose. Lane 9: HB2151 pComb3X with $0.2 \%$ glycerol. Lane 10: Protein marker.

Blue) was in the form of $\mathrm{scFv}(27.5 \mathrm{kDa})$ that fused to the linked $\mathrm{His}_{6}$ tag $(0.66 \mathrm{kDa})$, HA tag $(0.99 \mathrm{kDa})$, and pIII protein $(22.44 \mathrm{kDa})$ at the carboxyl terminal. The translational stop codon (UAG) was placed at the junction between the antibody and gIII protein sequences (Andris-Widhopf et al., 2000). These stop codon suppressor strains do not recognize the stop codon on the transcript and allow the scFv-pIII fusion protein to be produced. This $\mathrm{scFv}$-pIII fusion protein is insoluble and tends to accumulate in the host cells periplasmic compartment. The size expected for this insoluble $\mathrm{scFv}$ protein is approximately $52 \mathrm{kDa}$. On the other hand, the $\mathrm{scFv}$ protein that was expressed in the strain HB2151 (Fig. 3), a non-amber codon suppressor strain, is in the form of $\mathrm{scFv}$ that is fused to the linked $\mathrm{His}_{6}$ tag and HA tag without pIII. This strain is able to recognize the stop codon at the 3 end of the $\mathrm{scFv}$ gene, and the synthesis of $\mathrm{scFv}$ will be halted upstream of $\mathrm{gIII}$. The $30 \mathrm{kDa} \mathrm{scFv}$ fusion that is produced is soluble and able to be secreted from the periplasmic space into the 


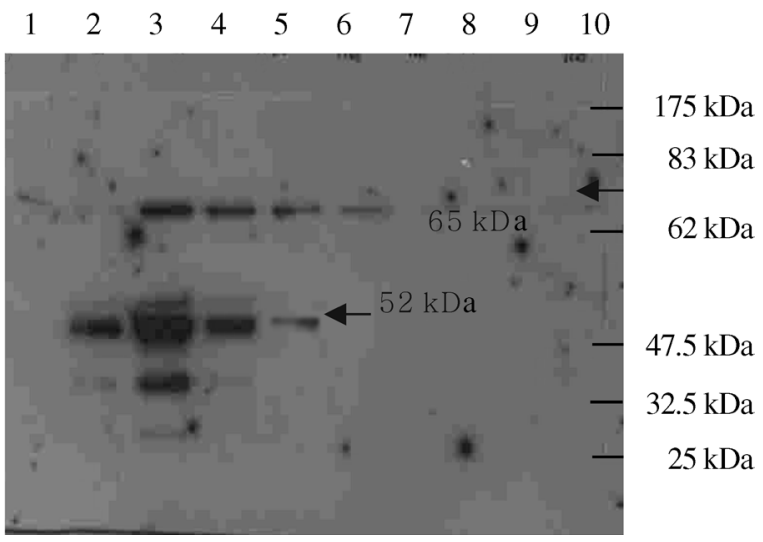

Fig. 4. Western blot profile of proteins expressed in XL1-Blue periplasm at different concentrations of glycerol fed under induction of $0.05 \mathrm{mM}$ IPTG. Expression of $\mathrm{scFv}$ is optimal at $0.05 \%$ glycerol. Lane 1: XL1-Blue without additional carbon source. Lanes 2-5: XL1-Blue Clone C4X with 0\% glycerol (Lane 2), $0.05 \%$ glycerol (Lane 3), $0.2 \%$ glycerol (Lane 4 ), $1.0 \%$ glycerol (Lane 5). Lanes 6-9: XL1-Blue pComb3X vector with $0 \%$ glycerol (Lane 6), $0.05 \%$ glycerol (Lane 7), 0.2\% glycerol (Lane 8 ) and $1.0 \%$ glycerol (Lane 9). Lane 10: Protein marker.

extracellular medium. Secretion of soluble scFv into the growth medium eases the harvesting of $\mathrm{scFv}$, especially for commercial production, while the accumulation of $\mathrm{scFv}$ within the oxydized periplasmic space permits a better and functional folding of $\mathrm{scFv}$. Some host proteins $(65 \mathrm{kDa})$ were also detected by Western blotting, due to the presence of the nine amino acids in certain $E$. coli proteins that can be detected by anti-HA (Roche Molecular Chemicals, 1999). The expression of pIII was precluded by the stuffer fragment in the pComb3X vector control cells, as previously described.

The scFv expression of Clone C4X in all of the host strains was optimal in the growth medium that contained an additional carbon source (i.e. glucose or glycerol) (Figs. 2 and 3 ). Therefore, there is a need to supply an additional carbon source for the enhanced protein expression. Glycerol at a concentration of $0.2 \%(\mathrm{v} / \mathrm{v})$ was shown to increase the $\mathrm{scFv}$ protein expression level when compared to $0.2 \%(\mathrm{v} / \mathrm{v})$ glucose. Since glucose catabolite repression occurs at concentrations greater than $1 \mathrm{~g} / \mathrm{l}$ (De Bellis and Schwartz, 1990), glycerol was then selected as the carbon source candidate for the study that is described below. Among the host strains that were used for the scFv expression, XL1-Blue exhibited the highest level of the scFv expression (Fig. 2) and was selected for the study on the $\mathrm{scFv}$ expression at different concentrations of glycerol.

Under the induction of IPTG (Fig. 4), the scFv expression in the periplasm of XL1-Blue-C4X increased when the concentration of supplemented glycerol increased from $0 \%(\mathrm{v} /$ v) to $0.05 \%(\mathrm{v} / \mathrm{v})$ with an optimal expression at $0.05 \%(\mathrm{v} / \mathrm{v})$ glycerol; it decreased when the glycerol concentrations increased from $0.2 \%(\mathrm{v} / \mathrm{v})$ to $1.0 \%(\mathrm{v} / \mathrm{v})$. This could be due to
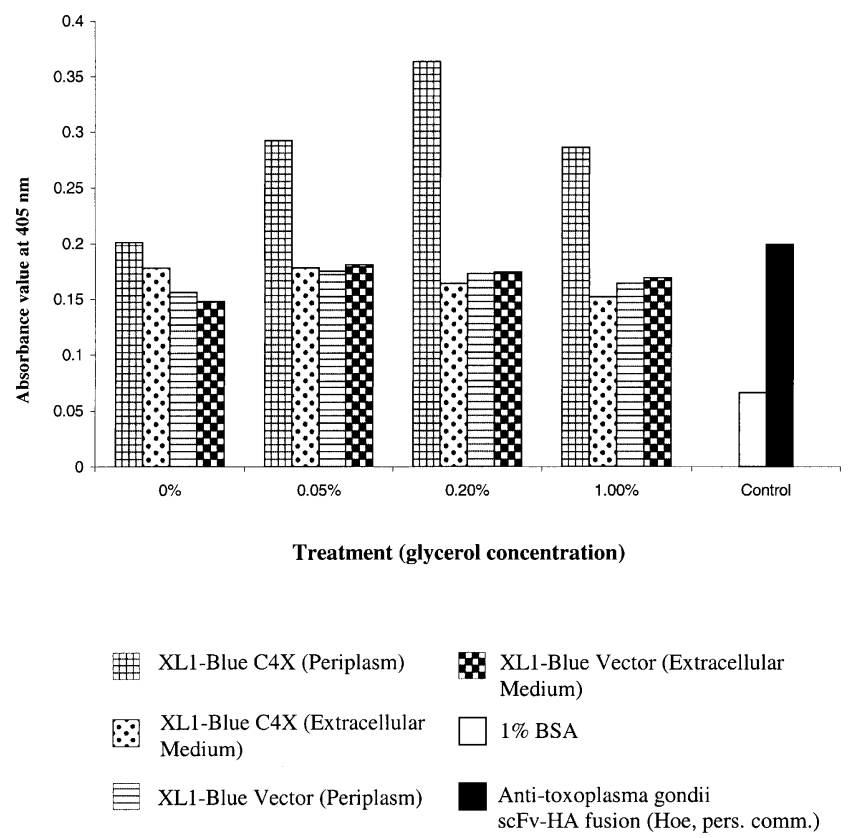

Fig. 5. Indirect ELISA of anti-B. pseudomallei exotoxin $\mathrm{scFv}$ expressed in XL1-Blue with different concentrations of glycerol supplementation.

the over-feeding of glycerol to the host cells, which enhanced glycerol metabolism and consequently led to the fast accumulation of dihydroxyacetone phosphate in the host cell. Accumulation of this metabolite led to the formation of methylglyoxal which was detrimental to the host cell (Lin, 1987). No $\mathrm{scFv}$ protein was detected in the extracellular medium of the XL1-Blue Clone C4X (data not shown).

Anti-B. pseudomallei exotoxin scFv affinity by indirect ELISA An indirect ELISA demonstrated that $\mathrm{scFv}$ antibodies that were expressed in the presence of all of the glycerol concentrations reacted positively towards the exotoxin (Fig. 5). The scFv that was expressed in $0.2 \%(\mathrm{v} / \mathrm{v})$ glycerol showed the highest affinity towards exotoxin in contrast to the $\mathrm{scFv}$ that was expressed in $0.05 \%(\mathrm{v} / \mathrm{v})$ glycerol, as previously described. This could be due to the overproduction of the $\mathrm{scFv}$ protein in the periplasm that leads to the formation of inclusion bodies when the expression is conducted in $0.05 \%$ (v/v) glycerol (Carrier et al., 1993; Karu et al., 1995). The inclusion bodies resulted in the accumulation of misfolded and incorrect conformation of the $\mathrm{scFv}$, hence decreasing the affinity of the antibodies towards its antigen (Carrier et al., 1993).

\section{Conclusion}

We successfully optimized the conditions for the expression of anti- $B$. pseudomallei exotoxin scFv by utilizing XL1-Blue as the host that is supplemented with a carbon glycerol source of 
$0.05 \%$. The ability to induce the scFv gene expression by IPTG permits the separation of cell growth from product synthesis, which results in higher total yields of the scFv protein when compared to the constitutive expression. The functional protein expression plays an important role in producing $\mathrm{scFv}$ that is able to react positively towards the exotoxin.

Acknowledgments This research was funded by the Ministry of Science, Technology, and the Environment, Malaysia (IRPA Grant: 09-02-02-0123).

\section{References}

Armstrong, N., Adey, N. B., McConnel, S. J. and Kay, B. K. (1995) Vectors for phage display; in Phage Display of Peptides and Proteins, Kay, B. K., Winter, J. and McCatterty, J. (eds.), pp. 38-54, Academic Press, San Diego, USA.

Andris-Widhopf, J., Rader, C., Steinberger P., Fuller, R. and Barbas, C. F. III. (2000) Methods for the generation of chicken monoclonal antibody fragments by phage display. J. Immunol. Methods. 242, 159-181.

Ashdown, L. R. and Koehler, J. M. (1990) Production of hemolysin and other extracellular enzymes by clinical isolates of Burkholderia pseudomallei. J. Clin. Microbiol. 28, 23312334.

Barbas III, C. F., Burton, D. R., Scott, J. K. and Silverman, G. J. (2001) Phage Display: A Laboratory Manual. Cold Spring Harbor Laboratory Press, New York, USA.

Carrier, M. J., Nugent, M. E., Tacon, W. C. A. and Primrose, S. B. (1993) High expression of cloned genes in E. coli. and its consequences. Trends Biotechnol. 1, 109-113.

Chaowagul, W., Suputtamongkol, Y., Dance, D. A. B., Rajchanuvong, A., Pattararechachai, J. and White, N. J. (1993) Relapse in melioidosis: incidence and risk factors. J. Infect. Dis. 168, 1181-1185.

De Bellis, D. and Schwartz, Ira. (1990) Regulated expression of foreign genes fused to lac: control by glucose levels in growth medium. Nucleic Acids Res. 18, 1311.

Donovan, R. S., Robinson, C. W. and Glick, B. R. (2000) Optimizing the expression of a monoclonal antibody fragment under the transcriptional control of the Escherichia coli lac promoter. Canadian J. Microbiol. 46, 532-541.

George, A. J. T. (1995) Production of antibodies using phage display libraries; in Monoclonal Antibodies: Production, engineering and clinical application, Ritter, M. A. and Ladyman, H. M. (eds.). pp. 142-165, Cambridge University Press, Cambridge, Great Britain.

Glick, B. R. (1995) Metabolic load and heterologous gene expression. Biotechnol. Adv. 13, 247-261.

Hausesler, S., Nimtz, M., Domke, T., Wray, V. and Steinmetz, I. (1998) Purification and characterisation of a cytotoxic exolipid of Burkholderia pseudomallei. Infect. Immunol. 66, 1588-1593.

Ismail, G., Noor Embi, M., Omar, O., Allen, J. C. and Smith, C. J. (1987a) A comparative immnunosorbent assay for detection of Pseudomonas pseudomallei exotoxin. J. Med. Microbiol. 23, 353-357.

Ismail, G., Noor Embi, M., Omar, O., Razak, N., Allen, J. C. and Smith, C. J. (1987b) Enzyme immunoassay for the detection of antibody to Pseudomonas pseudomallei exotoxin in mice. FEMS Microbiol. Lett. 40, 27-31.

Ismail, G., Rahmah, M., Rohaya, S., Sharifah, H. S. M. and Noor Embi, M. (1991) Antibody to Pseudomonas pseudomallei exotoxin in sheep exposed to natural infection. Vet. Microbiol. 27, 277-282.

Kanai, K. and Kondo, E. (1994) Recent advances in biomedical sciences of Burkholderia pseudomallei (basonym: Pseudomonas pseudomallei). Jpn. J. Med. Sci. Biol. 47, 1-45.

Karu, A. E., Bell, C. W. and Chin, T. E. (1995) Recombinant Antibody Technology. ILAR J. 37.

Laemmli, U. K. (1970) Cleavage of structural proteins during the assembly of the head of bacteriophage T4. Nature. 227, 680685.

Lin, E. E. C. (1987) Dissimilatory pathways for sugars, polyols and carboxylates; in Escherichia coli and Salmonella typhimurium: Cells and Molecular Biology, Ingraham, J. L., Low, K. B., Megasanik, B., Schaecther, M. and Umbarger, H. E. (eds.). pp. 244-284, American Society of Microbiology, Washington D. C., USA.

Ling, J. M. L., Nathan, S., Lee, K. H. and Mohamed, R. (2001) Purification and Characterization of a Burkholderia pseudomallei Protease Expressed in Recombinant E. coli. J. Biochem. Mol. Biol. 34, 509-516.

Nathan, S., Li, H. B., Rahmah, M. and Noor Embi, M. (2002) Phage display of recombinant antibodies toward Burkholderia pseudomallei exotoxin. J. Biochem. Mol. Biol. Biophys. 6, 4553.

Nathan, S., Rahmah, M., Pillai, R., Lai, K. Y. and Noor Embi, M. (2000) Production and characterisation of anti-Burkholderia pseudomallei exotoxin monoclonal antibodies. J. Biochem. Mol. Biol. Biophys. 4, 17-25.

Puthucheary, S. D. (1994) Laboratory diagnosis of melioidosis; in International Symposium on Melioidosis: Prevailing Problems and Future Directions, Puthucheary, S. D. (ed.), pp. 250-252, Kuala Lumpur, Malaysia.

Rader, C. and Barbas, C. F. III. (1997) Phage display of combinatorial antibody libraries. Curr. Opin. Biotechnol. 8, 503-508.

Rahmah, M., Nathan, S., Noor, E., Nyonya, R. and Ghazali, I. (1989) Inhibition of macromolecular synthesis in cultured macrophages by Pseudomonas pseudomallei exotoxin. Microbiol. Immunol. 33, 811-820.

Roche Molecular Chemicals. (1999) Anti-[HA]-Peroxidase mouse monoclonal antibody clone 12CA5. Roche Mol. Chem. Newslett. 1, 1-5.

Thibault, F., Cociancich. S, Paucod, J. C., Gignoux, F., Thibault, I. and Vidal, D. (1996) Purification of a 42,000 mol. wt protease from Burkholderia pseudomallei. Toxicon 34, 1096.

Towbin, H., Staehlin, T. and Gordon, J. (1979) Electrophoretic transfer of proteins from poliacrylamide gels to nitrocellulose sheets: procedure and some applications. Proc. Natl. Acad. Sci. USA 76, 4350-4354.

Vorachit, M., Lam, K., Jayanetra, P. and Costerton, J. W. (1995) Electron microscopy study of the mode of growth of Pseudomonas pseudomallei in vitro and in vivo. J. Trop. Med. Hygiene. 98, 544-546.

Yabuuchi, E. and Arakawa, M. (1993) Burkholderia pseudomallei and melioidosis: $\mathrm{Be}$ aware in temperate area. Microbiol. Immunol. 37, 823-836. 